\title{
Multiculturalism in Kavita Dasvani’s Lovetorn
}

\author{
Dr. Ganesh Vijaykumar Jadhav \\ Head \&Assistant Professor \\ Department of English \\ Dhananjayrao Gadgil College of Commerce \\ Satara, Maharashtra, India \\ jadhavganeshv@gmail.com
}

\begin{abstract}
Multiculturalism is a mechanism of interconnected ingredients and their experiences with each other as well as with the present world. It is a kind of respecting others' very existence and identity. In specific ethnic minorities especially the women and low caste people are not identified with their self or existence. Respect is the practice which teaches to treat others with some reverence and modesty. It protects and values the dignity and social worth of an individual. It also acknowledges the social differences, because every group has its own specificity. Multiculturalism considers it because the minorities' contribution to the society is empowering the society and taking it to a position of next and better destination. Uma Parmeshwran rightly argues in her article, "Home is home where your feet are, and may your heart be there too" that "literature can play an important role since literature not only reflects persistence and change in society but also can lead society to a better appreciation of its multicultural and ethno-centered fabric. The ethnic emigrant writer either writes about the country in which he is presently residing, like the main stream writers do, and thus try to be like 'them' or he can write about his ethnic world and be different" (31). In the present paper
\end{abstract}


the major focus is on the multicultural aspects in context with various situations. Characters behaviour in different multicultural situations is the angle of analysis of the researcher.

Keywords: Multiculturalism,diaspora, transnationalism, alienation, home etc.

Multiculturalism is a mechanism of interconnected ingredients and their experiences with each other as well as with the present world. It is a kind of respecting others' very existence and identity. In specific ethnic minorities especially the women and low caste people are not identified with their self or existence. Respect is the practice which teaches to treat others with some reverence and modesty. It protects and values the dignity and social worth of an individual. It also acknowledges the social differences, because every group has its own specificity. Multiculturalism considers it because the minorities' contribution to the society is empowering the society and taking it to a position of next and better destination. In the present novel the major concerns of multiculturalism is analysed with reference to various characters.In the present novel the major concerns of multiculturalism is analysed with reference to various characters. This is exhibited in the initial part of the novel as

The principal's office was at the far end of the corridor. Her secretary took our names before knocking on the principal's open door to tell her that we were here. Mrs. Meyers was like no school head I had ever seen. My old headmistress in Bareilly was a plump and bespectacled woman, always clad in a sari and sporting a huge red bindi in the middle of her forehead. But Mrs. Meyers looked young, was very thin and had a pleasant smile on her lightly freckled face. She wore an orange shirt tucked into a fitted gray skirt (Dasvani, 21).

Shalini here compares her school teacher in India and that of Los Angeles. She compares them because an appearance of a teacher matter a lot for the students. It creates impression on 
their minds. She thinks that the Indian teacher believes in simplicity. On the other hand the foreign believes in well neatness.

Another woman walked me up a flight of stairs to get to my classroom. It was bigger and more crowded than I expected. All the other students were already seated, and looked up at me when I walked in. Some murmured, some giggled. Two girls, seated next to each other in the second row, nudged each other and pointed to my dress, chuckling into their hands. One was wearing a T-shirt with a glittery peace logo on the front. The other had three earrings studded in her left ear(Dasvani,23).

In the multicultural scenario the diasporic characters have to adjust with the new environment. Shalini being the new admission in the school was taken to her class. The eyes of the girls stare at her in a different way. But she tries to assimilate in this new class. She also notices the new things in the classroom which differs from her class in India.

In the center was a tall statue of the blue-skinned Krishna, his baby face framed by bouncy, black porcelain curls. His rose petal lips were curled around his flute, his most potent instrument, intoxicating all who heard it, and bringing gopis-the maidens-to their soft-skinned knees. Here, in this otherwise plain room, the golden flute on the statue stood out like a beacon (Dasvani,30). Mrs. Asha Agarwal tries to forget her sorrow by involving herself in the worship of lord Krishna. Lord Krishna's flute is the most powerful instrument to forget the sorrow. She also worships the same God to come out of the problem in the host land.

I stepped inside and stood in front of the shrine. The stone figure if Durga was painted in bright, garish colours. She was sitting atop, her eyes wild, her ten arms carrying myriad of weapons. Under her golden, gem-studded crown, her hair was long and loose. I realized now, staring at her, that I had never really 
looked at her before, that this statue-like so many I had grown up with, in our family temple in India-was just another piece of carved and decorate stone that I had bowed to every morning. I realized I hadn't prayed since we left India. Given the way I was feeling now, empty and lonely, it seemed a good time. I looked straight into Goddess Durga's wide eyes, folded my hands together, bowed my head, and prayed that tomorrow at school would be better(Dasvani,30-31).

India is the country of Gods and deities. People are hypnotized by the effect of God and its miracles. Even in the hostland people remember the God in the homeland because they feel that they are the savior of them in the miserable condition. Praying to God every day gives all the migrant Indians a kind of peace of mind. Sangita thinks that though the pervious day was not good the next will be better.

Although my father's boss, Mr Jairam Thakker, was Indian, he liked to be called Jeremy. Jeremy Tucker. Or, as Sangita and I would refer to him, Mr Jeremy.

My father would talk enthusiastically about him, his smarts, his vision, his drive. Work was going great, my father would assure. This was really the right move...(Dasvani,32).

In the multicultural scenario the migrant Indians tend to change their names Sitaram wants to be renamed as Sam, Jotiram wants to become Jonathan and many other such examples can be cited. In the same way Jairam wants to become Jeremy. Even Shalini and Sangita calls him with the new nomenclature.

'So you're straight from India?' she asked, ushering me into a room in the back which had posters on the walls if big-haired women in shiny evening gowns. 
'Yes, I've just come here a few months back.'

'Hah, but you are a girl in America now,' she said, pushing me gently into a chair and pulling out a spool of white thread from her pocket. 'Here, everything happens early.'(Dasvani,87)

Shalini goes to the parlour and meets Prema, a parlour woman. She identifies Shalini as she is the new comer in America. The name itself suggests that she is an Indian. She talks with Shalini as a known person and also tells her that she is now a girl from America and she have to follow the new lands' rules. This experience gives Shalini how to behave in the multicultural backdrop.

At the restaurant, I decided not to think about my mother. The evening was so much fun, and I didn't want anything to spoil it. Renuka, Sangita, and I sat at one end of the table, sipping Coke in frosted glasses. Renuka said my new outfit looked 'sick', which I was given to understand was a good think in Renuka-speak. We giggled about Vikram. Renuka asked if she could try on the ruby ring and I let her. She held up her hand in front of her, clapped, and said, 'Yay!' Then she covered her head with her napkin and pretended to be a blushing Hindu bride, and we giggled some more. When she gave back the ring, she forced a pout, and said, 'Boo hoo'. I looked at the sparkling little ruby proudly. Mr Jeremy raised his glass of wine and toasted my father, wishing him a 'happy semi-anniversary', thanking him for his work. And my sweet father looked radiant with pride and joy. I so deeply wished my mother had been there to see it.(Dasvani,105)

Shalini and other friends come together and talk about the Hindu rituals like engagement. Mr. Jeremy wishes Mr. Agarwal of half period spent in Los Angeles. He is great source to bring 
together all Indians and celebrate various occasions. But Shalini remembers her mother on this occasion. If she could be present on that occasion then the happiness might be doubled.

I knew they were making fun of me. I felt the heat rise to my cheeks and squirmed imperceptibly. I hadn't been here for thirty seconds, and was already miserable. I hated it and wanted to turn around, run out the door, back down the stairs and catch up with my father and beg him to take me home-not the new one here, but our real home, the one eight thousand miles away, the one we never should have left(Dasvani,23-24).

Shalini gets disturbed by the treatment in the class. The girls make fun of her and tease her. Therefore she is perturbed and requests her father to take her to her home which is eight thousand miles away from her present home. Home is such a thing where all the beings feel secure. But in this new land she doesnot feel the same.

At home, as I went to change, I stopped at the doorway of the bedroom that was to have been Sangita's. My mother had transformed it into a makeshift temple. She had brought everything to replicate the daily prayers ceremonies of our home in India. A low dresser was overlaid with one of her saris, a flowing blue-and-gold fabric that smelled of her. Over it she had placed a dozen figurines of Hindu deities-the God's Ganesh, Vishnu, and Shiva, the goddesses Parvati, Laxmi, and Durga(Dasvani,30).

Mrs. Asha Agarwal feels very sad due to her migration to Los Angeles. She wants to forget her sorrow by praying God. She converts Sangita's bedroom into a kind of temple. Before her immigration she collects all the material for worship. Due to existence of these deities Shalini thinks that she is at home.

'So what happened? All the call center jobs were taken and you had to come here?' smirked Charlie. Another boy with him laughed. 'You know, my dad 
lost his job' cuz it was outsourced .One of you people must have taken it.' His voice was menacing. Sangita put her hand on top of mine. Tears stung my eyes. My mind raced frantically to think of something to say. But nothing struck me that moment. I was trembling, and felt humiliated and speechless (Dasvani,28).

The diasporic people migrate for their jobs but due to their migration and acquisition of jobs the native people loose their jobs. Charlie expresses the same thing. Shalini gets insulted due to this remark by Charlie. Another boy says that his father has lost his job because of the outsourcing. No doubt the migration makes the life of diasporic people happy however it creates some bad impact on the lives of the foreign people. Their restlessness and pangs can be seen in the above context.

My father looked over at us, aghast. In all his purchase yesterday, it had not occurred to him to buy beer. 'I'm sorry but we don't have any,' I said. 'It's no problem,' my father shouted, jumping up. 'I'll run down to 7-Eleven. It's just around the corner. Please tell me which brand I should buy?'

'Relax," my father's boss replied. 'I can do without. A Coke would be fine. Anyway, I brought this.' He handed me the bag in his hand. I looked inside; it contained a bottle of wine 'Maybe we can enjoy it together later, over dinner?'(Dasvani,61-62)

Mr. Jeremy, the boss of Mr. Agarwal visits the house and at that time this family welcomes him. But unfortunately they have no drink to welcome him as per their culture. This kind of cultural differences occur many times in diasporic communities. They have good storage of cold drinks but they do not have the drink which Mr. Jeremy wants.

'Actually, Jeremy, I don't drink, and neither does anyone in my family,' my father said reluctantly. Jeremy looked surprised. There was no 
reason he should have known that; this was the first time my father and his new boss were socializing. But it was true: my grandparents had a strict nomeat and no-alcohol rule, although I often wondered how my make cousins coped when they went with their friends to some of Bareilly's famous clubs.(Dasvani,62)

In Indian culture meat and wine are prohibited. Many people who visit the foreign country avoid these things. This happens due to the cultural differences which Mr. Agarwal follows very honestly. Shalini wonders how her make cousins adjust when they go to the club houses in Bareilley.

The close reading of Kavita Dasvani's novel Lovetorn reveals that her characters truly represent the consciousness of the immigrant people. After the scrutiny of her present novel it becomes clear that protagonist of her novel is deeply conscious about their Diasporic identity, resultant alienation, nostalgia and the basic concerns of Diaspora. In this sense the present novel exhibits multiculturalism and are mainly concerned with their search of the diasporic self in the transnational world. Shalini compares the cultural variation in India and America. She compares the values of the teachers in both the places. Mrs. Asha Agarwal also tries to assimilate in the new environment which is also another quality of diasporic people. They try to adjust with the new environment and value system because that is the only thing which helps them to survive. The same thing is communicated by Prema to Shalini which is girl working in the parlour. In short all the major characters show that they follow the multicultural ethics in the host land which is the principle concern of the present paper. 


\section{Works Cited}

Dasvani,Kavita. Lovetorn Harpertin, 2012.Print.

Bhabha, Homi. The Location of Culture. London: Routledge, 2010. Print.

Bharucha, Nilufer E. "Charting of Cultural Territory: Second Generation Postcolonial Indian English Fiction.” The Postmodern Indian English Novel. ed. Viney Kirpal. Bombay: Allied, 1996. Print.

Bissondoyal, B. The Truth About Mauritius. Bombay: Bhartiya Vidya Bhavan, 1993.Print.

Brah, Avtar. Cartographies of Diaspora: Contesting Identities. London: Routledge, 1996.

Print.

Braziel, J. E. and A. Mannur. Theorizing Diaspora : A Reader. Blackwell (UK), 2003. Print. 